\title{
Innovative Research on Talent Cultivation under the Mode of University-enterprise Cooperation
}

\author{
Jian Bai*; Yanqin Yu; Jianying Zhao; Jian’e Xue; Jun Li; Fang Guo; Rui Wang; Ping Gao \\ Department of Life Science \\ Lüliang University \\ Shanxi 033001, P.R. China \\ *Corresponding author:1920997201@qq.com
}

\begin{abstract}
This paper takes the University-enterprise cooperation of the biological science major of Lüliang University as an example. Through the questionnaire survey and interviews with relevant personnel, we can comprehensively investigate the situation of University-enterprise cooperation in Lüliang University. The results show that University-enterprise cooperation is good for students to think, discover problems and adopt their own unique methods to solve problems and take the initiative to take responsibility. University-enterprise cooperation is one of the best ways to cultivate students ' innovative ability.
\end{abstract}

Keywords-University-enterprise cooperation; innovation ability; investigation and research

\section{INTRODUCTION}

University-enterprise cooperation means adopting the mode of cooperation between schools and enterprises and cultivating talents for enterprises in a targeted manner[1]. It is an educational cooperation mode established between schools and enterprises. By cultivating the practicality and effectiveness of talents, this cooperation combines students' learning in school with corporate practice, school teaching and enterprise resources and information to achieve the needs of adapting to the society, integrating with the market, and cooperating with enterprises to achieve practice and The principle of sharing and win-win[2].

From the perspective of the biological science major of the Life Science Department of Lüliang University, it is the training target of the professional to cultivate the applicationoriented talents with certain cultural level and professional knowledge and skills[3].To this end, from the perspective of complementary advantages and knowledge sharing, this paper finds through the investigation of Lüliang University, enterprises and students that the implementation of Universityenterprise cooperation mode pays more attention to the cultivation of students' practical ability in the process of cultivating students' innovative ability. The transformation of theoretical knowledge lays a good foundation for the next step to better compete in the front line of production[4]. This method has a practical guiding significance for promoting students' innovative ability building, improving students' comprehensive quality, and promoting students' smooth transition from the student learning stage to the production practice stage[5].

Sponsors: Shanxi education science 13th five-year plan 1331 project (ZX-18089) from Shanxi education scientific research institute.

\section{SURVEY OBJECT, CONTENT AND METHOD}

\section{A. Surveyobject}

50 teachers from the Life Science Department of Lüliang University, 200 graduated students and 400 students in the biological sciences (600 students in total), Wenshui County Jinke Bio-Ecological Development Co., Ltd. and 60 workshop leaders.

\section{B. Surveycontent}

To investigate the University-enterprise cooperation of Lüliang University's biological sciences, we mainly understand the status quo from the following three aspects. First, from the school aspect to understand the situation of students in the enterprise, to examine whether students' innovation ability has improved; Second, from the enterprise side, can students cultivate their innovative ability in the enterprise, is it effective? Third, from the perspective of students, what can they learn in the enterprise, can they really be qualified for the positions required by the company? Can students improve their ability to innovate? Finally, the survey data is summarized and analyzed.

\section{Surveymethod}

Comprehensive use of education survey method, literature review method, statistical method and other methods and means, the combination of theoretical research and empirical research, qualitative analysis and quantitative analysis, combined with the overall research and classification research to ensure the scientific nature of the research.

\section{RESULTS AND ANALYSIS}

\section{A. survey results of school on the development of students' innovative ability}

TABLE I. SURVEY RESULT S OF SCHOOL ON THE DEVELOPMENT OF ST UDENT S' INNOVATIVE ABILITY

\begin{tabular}{ccccccccccc}
\hline Test Items & 1 & 2 & 3 & 4 & 5 & 6 & 7 & 8 & 9 & 10 \\
\hline Survey Result(\%) & 85.0 & 87.5 & 87.5 & 90.0 & 82.5 & 87.5 & 90.0 & 90.0 & 82.5 & 85.0 \\
\hline Note: The above test items & $1-10$ & respectively indicate: & 1 & Whether the student has a unique \\
performance through training in the enterprise. 2 Whether the students have their own unique ideas and \\
opinions through training in business. 3 Whether the student has the clue to complete the task through the \\
exercise in the enterprise. 4 Whether students have the spirit of hard work through the enterprise. 5 Can \\
students humbly accept criticism by exercising in the enterprise. 6 Can students calm down and seriously \\
think about problems by exercising in the enterprise. 7 Whether the students see the problem is not one-
\end{tabular}


sided through the exercise in the enterprise. 8 Whether the student completes the task does not delay the exercise through the enterprise. 9 Whether the student has the responsibility to take the initiative through the exercise in the enterprise. 10 Whether students are fair through exercise in business. The absciss positive attitude. The total number is 50 .
pare ind

It can be seen from table1 that the teachers of the life sciences department generally believe that the students who have participated in the enterprise training have the ability to innovate in the internship and writing of thesis and the innovation ability of the students entering the society. There is a noticeable improvement. According to the survey results of the above 10 test questions, the absolute number of people with a positive attitude is $82.50 \%$ and the highest is $90.00 \%$. During the teaching process of the life sciences department teachers, these students have changed greatly through training in the enterprise and returning to school. Most of them can handle some things in life independently, and they are not impetuous, learn to think seriously, and can reasonably treat people and things around them. Think rationally about problems. There are also some students who go to the society, and their ability is much stronger than that of some students who are not trained in the enterprise; and they show an amazing side from being a person to working. The results of practice show that University-enterprise cooperation can promote the organic integration of professional education and innovation and entrepreneurship education, integrate innovation and entrepreneurship education into the whole process of talent cultivation; promote the connection between professional chain and industry chain, interface the curriculum content with professional standards, and link the teaching process with the production process. Cultivate the connection with economic and social development, entrepreneurial employment needs, formulate talent training programs that are in line with the school's training objectives and have distinctive characteristics, build a high-quality applied technology and skill-based personnel training system, and vigorously cultivate moral, intellectual, physical and aesthetic The comprehensive development of application, technical and technical talents in the first line of production, construction, service and management.

\section{B. Survey results of enterprises on the cultivation of students' innovative ability}

TABLE II. SURVEY OF THE CULTIVATION OF ST UDENTS' INNOVATIVE ABILITY

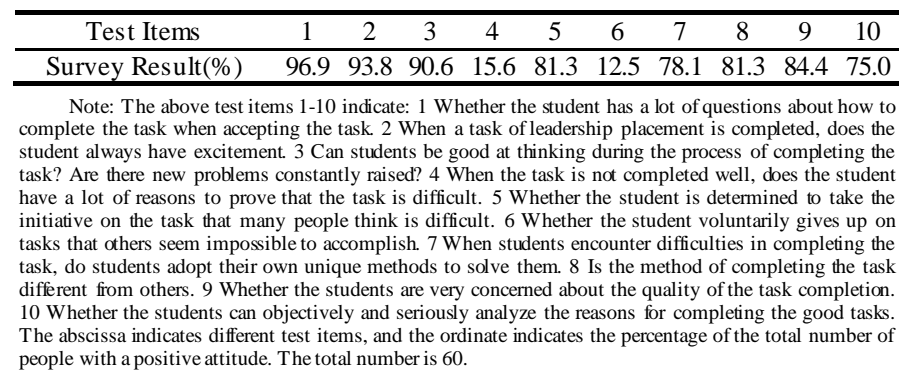

It can be seen from table2 that the students of Wenshui County Jinke Bio-Ecological Development Co., Ltd. believe that the students of our school have performed very well and have outstanding abilities in the training of students' innovative ability in the biological science major of Lüliang University. Through the survey results of the above 10 test topics and the person in charge of the company, more than $75 \%$ of the students are satisfied with the tasks completed by the company. The person in charge of the company emphasizes that through the combination of University and enterprise, the combination of in-class teaching and extracurricular exercise can indeed enhance students' morality and responsibility, innovation and entrepreneurship, interpersonal skills, social adaptability, physical and mental quality, humanity and professionalism. Cultivation[6]. Moreover, in terms of University-enterprise cooperation, focusing on cultivating learners' technical skills and innovative entrepreneurial abilities, students can quickly enter the society and integrate with reality, making them an indispensable intermediary bridge between schools and society. This is the need of students' career and sustainable development, and it also provides a strong guarantee for their employment.

\section{Survey results of students' self-innovation ability training in enterprises}

TABLE III. SURVEY OF STUDENT S' INNOVATION ABILITY IN THE ENTERPRISE

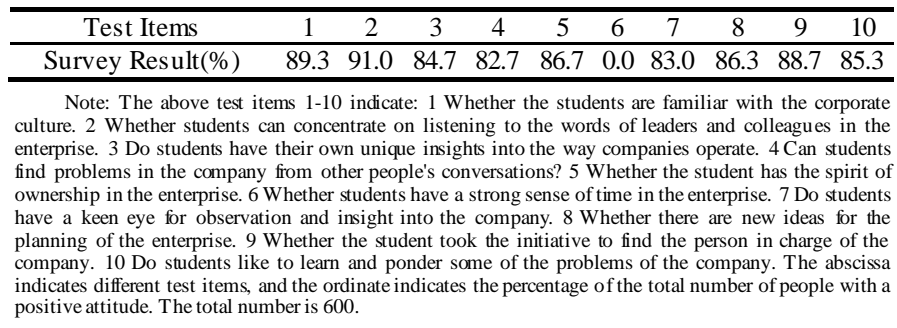

As can be seen from table 3, over the past year, more than $80 \%$ of students in the company's internships and writing graduation thesis and graduated students are optimistic about exercising in the enterprise. Students in the school believe that through the exercise in the enterprise, they have learned the knowledge that is not available in the book and have increased the flexibility, adaptability and practicality of the course structure and learning content, and the students' practical skills and innovative ability have been greatly improved. Students have ideas and learning skills to solve problems[6].The graduated students believe that through University-enterprise cooperation, they naturally transition to society without a sense of strangeness and discomfort to the society, but have a sense of nature and accomplishment. These changes are thanks to the enterprises providing good opportunities for practical training, realizing the transformation of teachers from knowledge transfer to comprehensive quality and practical ability training; highlighting the importance of training students' application ability. Teachers can grasp the connotation of applied talents as a whole and ensure the realization of application-oriented talents [7]. 


\section{DisCUSSION}

\section{A. Schools' Views on the Cultivation of Students' Innovative Ability}

The results of this survey show that the teachers of the Life Science Department of Lüliang University are very positive about the improvement of the students' ability to innovate in the biological sciences. The data shows that $85.00 \%$ of students have a unique performance through training in the enterprise. $87.50 \%$ of students have their own unique ideas and opinions by exercising in the enterprise. $87.50 \%$ of the students have a clue to accomplish the task by exercising in the enterprise. Especially those who have graduated have performed very well in all sectors of society, and some have even become the heads or leaders of the industry. Teachers believe that the ultimate goal of students learning at school is to go to the society, realize their own value in society, and achieve the purpose of learning. We believe that the bridge to the society is a enterprise. Students who exercise in the enterprise actually contact the society earlier and enter the society in advance, laying a solid foundation for real entry into the society in the future. University-enterprise cooperation can enable students to have psychological preparations for entering the society on the one hand, and the process of enterprise training is the process of improving their ability to innovate. $90.00 \%$ of students have a hard working spirit by exercising in the enterprise. $82.50 \%$ of students can accept criticism with humility by exercising in the enterprise. $87.50 \%$ of students can seriously think about problems by exercising in the enterprise. $90.00 \%$ of students do not look at the problem by exercising in the enterprise. Through these four data analysis, the teachers found that most of the students who have exercised in the enterprise are not afraid of suffering, not afraid of being tired, and have the spirit of hard work and hard work; And afterwards, they can calm down and think about the problem, and see the problem more comprehensive, which is obviously different from the students who have not participated in the enterprise exercise. $90.00 \%$ of the students are no longer procrastinating through the exercise in the enterprise. $82.50 \%$ of the students have taken the initiative to take responsibility for their work in the enterprise. $85.00 \%$ of students can treat people and things fairly by exercising in the enterprise. From the above three data, the teachers found that some students who have undergone enterprise training have returned to the school and changed their normal status. There are obvious progress, the students are profitable, responsible, and responsible; they can treat people and things objectively and fairly, especially when they enter. Some of the students in the society are now well established in the society and have made some achievements. These achievements are very inseparable from their experience in corporate training. Teachers concluded that corporate exercise can indeed cultivate students' innovative ability in an intangible way, and is a positive and beneficial way of education for students.

\section{B. The view of enterprises on the cultivation of students' innovative ability}

According to the results of this survey, the company has a high evaluation of students in the biological science major of Lüliang University. The survey data shows that $96.88 \%$ of students accept a task; there are a lot of questions about how to complete the task. The person in charge of the company said that the students just entered the company, they are not very familiar with the company, and the problems are very normal. Asking more questions is a good thing and a good start to fostering innovation. When $93.75 \%$ of students complete a task assigned by the leader, there is always excitement. $90.63 \%$ of the students are good at thinking in the process of completing the task, and constantly have new questions. Business leaders believe that this phenomenon is very good, and the interest is the first teacher, who is interested in doing the task well. When the task is difficult, only $12.50 \%$ of the students voluntarily give up, and $15.62 \%$ of the students have a lot of reasons to prove the task is difficult. On the contrary, $78.13 \%$ of students can take their own unique methods to solve difficulties. The person in charge of the company believes that most students are still able to face difficulties and find ways to overcome difficulties and complete tasks. Of course, the difficulty is the best test for cultivating students' innovative ability. The process of overcoming difficulties is the processes of improving the ability to innovate. $84.38 \%$ of the students are very concerned about the quality of the task. $75.00 \%$ of students can objectively and seriously analyze the reasons for completing a good task. The person in charge of the company believes that these two instructions indicate that most of the students are enterprising, not only do they care about the quality of the tasks, but also objectively analyze the completed tasks. Only in this way can students have innovation and progress.

\section{Students' views on the cultivation of their own innovative ability}

This survey shows that students are satisfied with the results of their ability to cultivate innovation through training in the enterprise. The data shows that $89.33 \%$ of students are well versed in corporate culture. $91.00 \%$ of students can concentrate on listening to leaders and colleagues in the enterprise. $84.67 \%$ of students have their own unique insights into the way companies operate. $82.67 \%$ of students can find problems in the company from other people's conversations. $86.67 \%$ of the students have a spirit of ownership in the company. From the results of these five surveys, students can think of the company as their own home; know the corporate culture well; listen to the words of leaders and colleagues; and actively discover the problems of the company. Some students report that only in this way can they exercise their abilities, especially their ability to innovate. On the contrary, only $7.63 \%$ of students do not have a strong sense of time in the enterprise. $83.00 \%$ of students have a keen eye for observation and insight. $86.33 \%$ of students have new ideas for corporate planning. $88.67 \%$ of the students took the initiative to talk to the person in charge of the company. $85.33 \%$ of students like to learn and ponder some of the problems of the company. The above survey results show that students want to do something in the enterprise. Most students believe that although they are tired and hard in the enterprise, they have a very obvious effect on improving their ability to innovate. The effect is remarkable and worth learning. 


\section{CONCLUSION}

The questionnaire surveyed on the innovation ability of students through University-enterprise cooperation found that the following two aspects are worth noting.

\section{A. The degree of participation of enterprises in University- enterprise cooperation needs to be improved}

The survey found that the degree of participation of enterprises in University-enterprise cooperation is not high, and there is not strong enthusiasm in teacher training, curriculum development, technical exchanges, financial support, equipment and facilities for schools, and interaction with students. The person in charge of Wenshui County Jinke BioEcological Development Co., Ltd. believes that the enterprise is only a place for students to practice, as long as the students are safe during the internship; in the technical guidance and integration into the production process, the students are taught advanced Production technology and production experience are more conservative. Some students report that during the internship, they only listened to the introduction of some advanced equipment by the company's instructors, and did not have the opportunity to try the operation. In reality, because of its direct confrontation with the market, enterprises have more advantages in terms of knowledge and technology innovation and practice than the school education system. Once this advantage is added to higher education institutions, the cultivation of innovative talents is bound to be a leap[8].

\section{B. School communication and exchange in University- enterprise cooperation needs to be strengthened}

The school belongs to the education system. Its advantage lies in the high efficiency and quickness of cultivating talents. At the same time, due to its mass production, it is difficult to improve the "innovation" of efficient and rapid "teaching and inheritance"[9]. In the process of University-enterprise cooperation, there will be many problems. To deal with these problems in a timely and effective manner is of great significance for the further development of Universityenterprise cooperation. To solve these problems, it is necessary to rely heavily on communication and exchange between the two sides of University-enterprise cooperation. In the actual situation, the school and the enterprise did not form a timely and effective communication mechanism[10].The survey found that teachers believe that the main solution to the problems related to University-enterprise cooperation is to seek help from leaders or colleagues, who rarely contact the company to resolve. On the one hand, because the work is busy, the company is not able to open the investigation of the company, on the other hand, the student is responsible for the internship in the enterprise, and the school or the teacher is not responsible. This has resulted in fewer and fewer opportunities to communicate and communicate with companies. If the person in charge of school or the teacher communicates with the enterprise, it will be more beneficial to understand the situation of the student in the enterprise.

In short, if we pay attention to solving the above two problems, University-enterprise cooperation can indeed become one of the good ways to effectively cultivate students' innovative ability.

\section{ACKNOWLEDGMENTS}

The work was supported by Shanxi education science 13th five-year plan 1331 project $(Z X-18089)$ from Shanxi education scientific research institute.

\section{REFERENCES}

[1] Senkai Lu, Di Liu, Jijue Wei. University-enterprise cooperation is the best mode for training applied talents in science and engineering in local universities[J]. Education and Vocation, 2012(11):26-28.(In Chinese)

[2] Ying Zi. Higher professional colleges and universities practical talented person innovation ability raise discussion [J]. Ch ina Modern Educational Equipment, 2011(17):126-128. (In Chinese)

[3] Xuelong Ma. Problems of the training goal for biology specialty in the newly-established universities [J]. Higher Education Forum, 2009(3):2325. (In Chinese)

[4] Qi Liu. Research on the second class construction in colleges and universities[J]. Education and Vocation, 2014(6):41-42. (In Chinese)

[5] Yonglai Li. The teaching innovation and practice on the course of salary management[J]. Technological Development of Enterprise, 2008,27(9):99-101. (In Chinese)

[6] Junfei Wang, Yujun Sang, Zuozhong Song. Innovation research and practice of applied talents cultivation mode in transitional universities[J]. Value Engineering, 2018(3):213-215. (In Chinese)

[7] Zhaoping Liu. Research on improving the entrepreneurial literacy of engineering college students[J]. Journal of Innovation and Enterprise Education, 2014,5(1):79-81. (In Chinese)

[8] Feng Qiu. Research on college student entrepreneurship education from the perspective of collaborative innovation[J]. Education Exploration, 2014(9):132-133. (In Chinese)

[9] Qinglan Zhu. Investigation and research on students' post-intern practice in higher vocational colleges - taking the biopharmaceutical specialty of Suzhou industrial vocational and technical college as an example[J]. Light Industry Science and Technology, 2014(8):195-197. (In Chinese)

[10] Jian Zhang, Dengfeng Zhao. Research on interactive mechanism of professional learning and social practice from the functionalism perspective[J]. Journal of Changchun University, 2018,28(2):53-58. (In Chinese) 